\title{
Flexible industrial work in the European periphery: factory regimes and changing working class cultures in the Spanish steel industry
}

\author{
EJ Gonzalez-Polledo and Irene Sabate
}

\section{Factory regimes and labour deregulation in the Spanish steel industry}

In 1982, Spain's accession to the European Economic Community and its incorporation to the European social market economy came with a promise of progress: Spain's way out of 'backwardness' in political, economic and cultural terms. Yet this promise also served as a legitimation for neoliberal policies that rolled out the privatisation of public holdings and the restructuring (reconversion) of the heavy industries (Narotzky 2016). Neo-corporatist agreements between political parties, labour unions, and the state promised a political and economic transition which set in motion deindustrialisation without outlining an alternative policy for those whose livelihoods depended on the industrial economy (Castells et al 1994). However, although the steel industry is no longer as central to Spain's economic development as it was under Franco's Regime ${ }^{1}$ (Martín and Comín 1990, 1991; Benton 1990; González 2004), steelmaking factories survive the constant threat of erasure that never actually materialises. Even after state and market led forces caused a sharp decrease in the number and quality of jobs available, steel jobs have now become precarious, and subject to new and changing global competitiveness standards.

Spain's particular combination of characteristics as a central and peripheral economy, or as a semiperiphery (Arrighi 1985), and its particular trajectory as a European liberal democracy, partly explains the specific vulnerabilities of its workforce in the face of neoliberalisation and globalisation. Indeed, six decades after the first integrated steel factory was set up in Asturias under Franco's regime, as global multinationals operate side by side with smaller producers, the meaning of working in the steel industry is now radically transformed. As Narotzky and Goddard (2015) have shown, the heavy industries played a central role in the political configuration of Europe after the Second World War, where industrial collaboration was seen as a crucial mechanism to foster mutual dependence while increasing economic 
rationalisation. Also in Spain, from the 1950s on, within the public-owned holding Instituto Nacional de Industria (INI) created by the Francoist regime, steelmaking stood up as one of the main industrial activities to be fostered by the State.

In this context, differences between state-owned and private companies emerged as a defining feature of cultures of work and working-class identities in the steel sector. Under the hegemonic factory regimes of State-owned companies, cultures of work and working class identities emerged hand in hand with the creation of company neighbourhoods around state funded factories, offering not only housing, but also leisure and social activities, and supported by strong ties around emergent labour unions and collectives of political resistance. This contrasted with the situation in private steel companies, where work cultures and identities were articulated around the most basic struggles for better working conditions. In that case, 'despotic' factory regimes framed 'the continual making, unmaking and remaking of labour forces and working classes - politically, economically and structurally - through the dual lens of dispossession and disorganization' (Kasmir and Carbonella 2014, 5).

A global crisis engulfed steel production in Europe from 1974, affecting steel firms with varied measures of economic liberalization, restructuring, privatization, asset destruction, offshoring, speculation and capital mobility. In order to interpret the impact of these recent and current developments on the steel industry, we take as a point of departure the distinct factory regimes described above. They reveal how the complex social relations that shape industrial change in particular localities and historical moments trump sweeping generalizations about the implications of industrial transformation (see Lee 2010, Reygadas 2002). As complex articulations where distinct power relations facilitate comparisons between different circumstances faced by a firm along its trajectory, or between firms in different locations or industrial sectors, factory regimes appear as a key factor shaping the experience of work. Evolving along differentiated histories of State intervention, labour and ownership relations, and newly exposed to the pressures of global competition, factory regimes continue to be an important analytic device to understand the differences through which particular, historically situated groups of workers adapt to, transform and contest abstract economic models. In a neoliberal atmosphere, and as a result of the unprecedented circulation of capital giving way to international competition for investments and global markets, the Spanish industrial workforce has 
been quantitatively reduced and dispossessed from many of their prior rights and entitlements

In this context, labour relations offer a unique lens to reflect on changing engagements between capital and state, framing how relations among workers, between workers and social agents, as well as international entities and partnerships, underpin economic logics and differentiate and unify working and cultural identities (Ong 1987; Carrier 1992). Indeed, as Narotzky and Goddard have noted, economic models 'become and are enacted through, the struggles are responsible agents in historically grounded practice: they are designed and settled -however fleetingly- in complex interactions between powerful and less powerful human actors' (2015:9). In line with that, the case of the Spanish steel industry shows how 'restructuring was not only the dismantling of a sector in crisis, but the disappearance of an organizational model [...] that affected the way of life of workers and their families' (Florido et al 2013: 893).

This article compares the transformation of work in two Spanish plants: SIDERSA, a large-scale integrated steel plant situated in the northern region of Asturias, which currently employs around 5000 workers, and ACERASA, a small-scale electrical furnace operating in the north-western region of Galicia, which employs around 200 workers. Our comparison aims to explore how their diverging trajectories and contrasting work experiences give rise to distinct cultures of work . While SIDERSA is perceived as central to the Asturian regional economy, ACERASA tends to go unnoticed in an area where the Navantia State-owned shipyards have traditionally been accorded greater historical and economic relevance. Through a historical and comparative analysis, we aim to illustrate how, although regional policies and global relations play an important role in the development of work cultures, it is the combination of structural factors and particular cultural relations that shapes class experiences, attitudes and affiliations. Furthermore, in line with anthropologists' contributions to understanding the tensions between history and economic relations (Narotzky and Smith 2006), the cases we discuss show that, while the transformation of the industrial sector had similar effects on neighbouring locations in terms of livelihoods and of labour relations, cultures of work significantly articulated class relations facilitating economic change or promoting cultures of resistance and class 
solidarity, and shaping the lives of workers and their social environments as they faced industry transformations over three decades.

\section{Cultures of work, class institutions, and uncertainty - remaking class under neoliberalism}

Factory regimes provide a key framework to understand the 'critical junctions' (Kalb 2005) that shaped key changes in the industry. Workers' relationships of belonging were shaped by company histories, and in particular, by class institutions and relations enabled by ownership and management cultures. The Asturian plant, SIDERSA, was a national development project created by the Instituto Nacional de Industria, receiving state support until 1994. During the Spanish transition to democracy, it was internationalised and eventually privatised as part of the process of European accession. Its fate during this process has been the object of regional disputes, but there is some consensus that, although the plant suffered similar transformations to other industrial enclaves, it was disadvantaged in the process ${ }^{2}$. However, part of the complexity of SIDERSA's ownership structure lied in its central role in the regional economy, as well as its position within the Atlantic industrial region. For Vázquez (1994), Asturias' position had always been one of disadvantage. Its geographical location at the periphery of Europe situated industrial production within international supply chains and markets but the unbalanced effects of European integration adversely affected the Asturian economy. A national strategy to pursue restructuring over reindustrialisation ${ }^{3}$ (Castells 1994; Agüera 1996), supported by the regional government of Pedro de Silva, led to the dismantling of heavy industry in pursuit of 'the new light economy' (Silva 1982, Buznego and Silva 2009, Montero 2002, González-Polledo 2015), which consisted in redefining industrial production away from the heavy industries, in relation to a fabric of medium scale, knowledgeintensive and high value-added industries, plus a new emphasis on brownfield regeneration. Years of state management specially during Franco's paternalist industrialism - created visions of privilege among workers who could benefit from social housing and social and community funding, while, as the factory expanded, these funding streams also created cleavages around workers that were exacerbated during restructuring and privatisation. After initial restructuring in the 1970's, the 
Asturian plant underwent key critical turning points that degraded labour conditions, limited union interventions in labour management, and linked technological automation to deskilling in the long process that led to privatisation. When the plant was privatised in 1997, to eventually become part of a large multinational group, a continued implementation of cost-effectiveness measures aimed to maintain profit margins despite fluctuations in global steel prices and demand, which often meant relocating production and services to suit its global structure of operations. The three unions that had a voice in shaping restructuring negotiations (Union General de Trabajadores, Comisiones Obreras and Union Sindical Obrera) saw their active membership and defacto power significantly curtailed during the long process of restructuring, but still had a significant presence at the time of our fieldwork.

By contrast, the ACERASA plant had always been in the hands of a private industrialist and did not transcend the traditional model of the family firm until the late 1990s, when the owners purchased two additional plants in Portugal. The internationalisation process contributed to greater levels of pressure on the staff, who were faced with competition between the Spanish and the Portuguese plants in terms of productivity and cost-effectiveness. However, ACERASA did not experience much change regarding working conditions, capital-labour relations, technological innovation or the training of workers. Its peripheral status within the industrial landscape of its surrounding region, where shipbuilding was the dominant activity, kept the firm and its staff relatively isolated from wider restructuring trends, maintaining the firm's relative market position despite changes in global market relations.

However, even though both localities have been deeply affected by global trends toward flexible production, the impacts of changing regional industrial policy on livelihoods, as well as the different role of state funded industrial activity in each region, has produced diverging effects among groups of workers. The making of particular work cultures entails the internalisation of a certain ideology about work. It is this ideological content of particular work cultures, what contributes to or prevents the acceptation of the demise of industrial work as 'inevitable'. In the first instance, these differences can be traced back to diverging 'work cultures' taking shape at each location, and within each plant. These work cultures include shared behaviours, perceptions, attitudes and values acquired and built by individuals through their 
insertion in work processes, which in turn modulate their social interactions beyond the work place (Palenzuela 1995: 13). Moreno (1997) also points out that the completion of industrial restructuring necessitates a parallel process of ideological restructuring. Consent with the new situation among the working class needs to be produced in order to neutralise potential resistance and protest among a labour force that is now divided among integrated, precarious and marginalized workers (1997: 14). Deeply assumed contents of traditional work cultures during the industrial era regarding workers' rights and State's responsibilities, as well as regarding the solidarities among workers and their fragmentation as a social class- need to be replaced by a fragmentation of collective identities and the re-signification of labour rights as the privileges of a shrinking minority. By means of the diversification of work experiences and the differentiation of working conditions for different sectors of the labour force, the shared 'cultural framework' that used to make collective action possible in the early years of industrial restructuring is currently being eroded (Roca \& Florido 2015). In this way, work cultures, understood as the result of workers' experiences in specific jobs and under particular relations of production (Moreno 1997), are being radically transformed. This is affecting the meaning and location of work in people's lives, its ability to shape local social life at large, as well as the representations and projections of society and collective wellbeing. In the current era of 'flexible' work, continuous work trajectories are replaced by a sort of permanent 'nomadism' or 'work migration' that prevents routines, professional socialization, and complicates the construction, assimilation and internalisation of work cultures (Lozano \& Palenzuela 2016:4).

Our fieldwork around these plants spanned over 2011 and 2012, encompassing indepth interviews with workers and their families, as well as industry representatives, union stewards, local historians and educators, as well as representatives of local authorities, social movements, and neighbourhood associations ${ }^{4}$. We mapped current changes affecting local communities through by contrasting local archives with participant observation and in-depth household structured interviews in former company neighbourhoods, through which we aimed to track changes in household composition, family income, and changes in living conditions. We conducted participant observation in and around the plants. Although we were not employed as operators (Cf. Burawoy 1979), we participated in social events in and around both 
plants where informal discussions about the current predicament and future of the industry were held.

Our fieldwork coincided with a particularly uncertain moment at both plants. Parallel to the deterioration of working conditions and the aggravation of exploitation entailed by flexibilisation, culturally specific organisational identities and dynamics are also changing rapidly in the context of 'late industrialism', where, as Fortun notes, 'the entanglements of business and government, of law and politics, of war and farming, of natural and technical systems is stunning, and sobering' (Fortun 2012, see also Mollona, DeNeve and Parry 2009). In the Asturian plant, the conditions of steel production irrevocably changed in the wake of the Washington Consensus, and flexible production, an emphasis on technological innovation and labour deregulation were rampant as the firm bounced back the effects of the 2008 financial crisis. Workers' bargaining power was neutralised as, like Burawoy predicted, they were 'forced to choose between wage cuts (...) and job loss. As a result, the fear of being fired is replaced by the fear of capital flight, plant closure, transfer of operations, and plant disinvestment' (1985:150). In the Galician plant, while the stability of the regular workforce did not seem endangered, fixed-term workers depending on subcontracted companies had almost disappeared from the workforce, as ACERASA's managers tried to cut down production costs and to limit the volume of outputs in order to deal with the crisis in the Spanish building industry, their main client. At this time, in both locations, the result of multiple policy and practice constraints, conditions in the industry had never been more precarious for workers - through multiple mechanisms from factory relations to the structure of European Works Councils (Gonzalez Begega 2011), and state deregulation of Multi National Corporations (Gonzalez Begega and Kohler 2010). But this precarisation did not deactivate, as our comparative ethnography highlights, the ability of work cultures and working-class identities to endure and adapt to the changing conditions of global capitalism. Rather, our article explores how, in the context of the quantitative decline of industrial production in Western Europe, persisting values and forms of belonging continue to foster collective action and articulate social histories, values of craftsmanship and political activism, despite the considerable transformations of experiences and values of industrial work and within the social structure at large. 


\section{Making steel in a steelmaking region in decline}

SIDERSA had been a large integrated state-owned steel enterprise that spread its operations over two neighbouring steelmaking plants situated $23 \mathrm{~km}$ apart. Founded in a coastal village as part of a national strategy to build a strong industrial base for Franco's autarkic economy in the $1950 \mathrm{~s}^{5}$, the factory was swiftly populated by migrant workers from neighbouring regions, and soon expanded to incorporate other private steel producing companies in the region. In 1973, SIDERSA was Spain's largest steel producer, employing 27000 workers, the result of an ambitious state plan to concentrate capacity. But after the global economic downturn that ensued after the1970s oil crisis, SIDERSA became a prime target for state-led industrial reconversion in preparation for Spain's European Accession (Laso 2003). The reconversion advanced a new model of production anchored in neoliberal principles which relied heavily on cost-reduction through labour adjustment and flexibility, process automation and outsourcing.

These changes were supported by wider regional deindustrialisation policies aimed at orienting the region towards a 'new light economy' (de Silva 1982), a way of moving the regional economy into the future after the inevitable transformation of skills and the availability of work. During fieldwork, we visited the historic site of SIDERSA's apprentices school, which for most of our interviewees was the most significant vestige of the unique steelmaking work cultures that emerged around the factory. The original Apprentices School, for many interviewees SIDERSA's 'trademark' and a symbol of the company's quality craftsmanship until its closure in 1982, was associated with quality employment. An apprentice we interviewed in his current role as head of the training department of the multinational, remarked that during the reconversion period members of the older generations struggled to get to grips with changes in the quality and availability of work, especially the rhythms of increasingly automated processes and a new atmosphere of competition within and across plants. As funding for the apprentices school ran out, professional training began to be carried out in underequipped state-funded centres, while specialised forms of in-house training aimed to provide on the job training ${ }^{6}$.

Although it is now long gone, SIDERSA's apprentices school and the culture of craftsmanship it promoted still resonated with the collective imagination of work 
among the steelworkers who had attended it (and those who for many reasons could not). Especially around company neighbourhoods created under Franco's project of industrial paternalism and still home to many (former) industrial workers, the School epitomised a lost ideal of the industrial worker, which many thought policy makers should return to in order to solve some of the industry's problems. As the remaining workers of the first generation retired, supported by pension schemes ${ }^{7}$, their historic expertise and traditional craftsmanship left with them, leaving a void of knowledge and skills. Further, the Apprenticeship School provided a model of working class identity (see Thompson 1989). For the second generation steel workers we interviewed, who were approaching retirement, the evolution of the School epitomised the intersection of their working class identities and their working lives. The apprenticeship school was not only a class institution. They stressed that through the training they were able to access the security associated with working in SIDERSA, as well as wider recognition in fields like business, politics, professional sports or cultural industries. Key figures in the labour movement, as well as intermediate and senior management in the company, shared their training years as apprentices. Linking professionalization, class formation, and the state project of industrial paternalism (Sierra 1990; Benito 1993), the School remained a relation between craftsmanship and social memory. The figure of the apprentice made tangible connections between work and social identity. At the time of our fieldwork, although long lost, the figure of the apprentice lived on in public debates around employment and quality of work among employers, government and social agents, who emerge from the fragmentation of labour and the proliferation of hierarchies through differential access to stable jobs, career progression and continued training.

The disappearance of the apprenticeship system in the early 1980s brought with it the fragmentation of industrial working-class identities, which came side by side with fresh cuts in company funding for social initiatives, and the beginning of the most intense restructuring period. Social agents working in the region, especially labour unions (namely the CCOO, UGT and USO), and to a lesser extent employers' associations, have attempted to fill this gap by funding ongoing personal development and specialist training schemes. Deskilling was not only instrumental in transforming work cultures in the industry, but debates around the implications of deskilling were central to union-led organised resistance to privatisation, but there was still a key 
point of contention. Union representatives we spoke to were concerned about the lack of employment opportunities for local young people, nothing that employers' search for 'quality' training in job applicants often disguised priorities of cost reduction.

Debates about deskilling and job quality revived the figure of the steelwork apprentice after the 2008 financial crisis, when unions and social agents highlighted the farcical nature of employers' interest in the historical figure of the worker, denouncing their lack of understanding of skilling in terms of class values. As training plans were mostly provided by foundations within the main labour unions since 2004, this happened on a contract basis agreed with company union branches. Rather than equalising access and providing more training, this system meant union branches and employers' associations were equally responsible for training provision, but the decreasing availability of public funds made it harder for unions to cope with deskilling.

The 'skill gap' created new divisions between a dwindling number of permanent staff and increased numbers of contract workers in the 1990s (Kohler et al 2007). The latter, employed by outsourced companies (around 3000 at the time of our fieldwork), used the same premises and shared workloads with their in-house counterparts, working on services such as maintenance and cleaning. However, contract workers did not have access to safety uniforms and equipment, had to work unpredictable shifts, and were routinely subject to hiring and firing practices as service contracts were replaced, though their jobs were guaranteed in labour agreements between their union and the company ${ }^{8}$. Although outsourcing practices increased during the $1990 \mathrm{~s}$ and early 2000s, in the past ten years SIDERSA has been moving towards internalising contract workers to maintain quality and training standards, a move seen to provide long-term cost-effectiveness through labour flexibility. Herme had spent twenty years at the factory working on maintenance of the hot strip mill, and had accrued 'around 400' short term contracts during this time. He summarised the differences between his work and that of company workers:

As a contract worker you do a bit of everything. If you were a company worker, you could stop doing a job if you feel the job should be completed by another colleague. But as a contract worker, I have to manage to finish every job. You have to use all tools. As a company worker, you may have a specialism, but that 
is not respected when you are a contract worker (Herme, contract worker and Contract Workers' Union Organiser)

As the workforce was laid off through early retirement plans and more production services were sold or outsourced, jobs in the steel industry became scarce, precarious and more competitive. Jobs at the factory involved greater technological expertise which was no longer covered in public training programmes.

With these changes, the workers' movement was also significantly transformed. Unionised SIDERSA workers highlight the bottom-up character of union organising in the early days and the unions' engagement with wider struggles for social change, which was lost during the long restructuring period. UGT, CCOO and USO unions split over labour reforms, and bottom-up, direct action strategies were progressively abandoned in favour of bargaining at plant level. Our interviewees confirm expert claims that the unions' bargaining strategies became conciliatory after this point ${ }^{9}$. Many linked the neoliberal transformation with the political processes of democratic transition and European accession when unions became the 'activist arms' of political parties. Multiple assembly methods, cultures of resistance, and indeed, collective positions vis a vis privatisation emerged around the three main labour unions, UGT, CCOO and USO. An UGT affiliate we interviewed, the director of a local newspaper, wrote in his book about the transformation of the steel industry in Asturias (Urbano 2003), that as the steel industry was irrevocably dismantled (see also Sáez and Díaz 2009; Laso 2001), the union movement began a new kind of 'hard, but responsible' unionism that would eventually shape the future of the industry. However, views from Comisiones Obreras contrast this optimistic standpoint. A lifelong organiser in this union, who was also one of the first women to enter the workforce, described how, as links between unions and political parties strengthened, the structure of organising changed the nature and scope of political participation on the shop floor:

'We focused on SIDERSA in terms of organising because it had so many workers. The first Works Committee we organised was a union organisation linked to the factory's Central Committee, a unitary organism representing workers in the plant. Workers did not need to be affiliated, all workers negotiated the working conditions of all workers. But UGT always preferred 
trade sections; they defend [worker's rights] but when we have to blow wind they don't hold a clear position' (Carmina Garrido, 2011)

Our participants' imaginings of history were punctuated by moments of collective action where change was seen as possible. The strikes of 1988 and 1991 were especially well remembered, as was the 1992 Iron March when thousands marched from Asturias to Madrid to demand that the government reconsider the privatization of the industry. Yet the bureaucratization of the unions did not go down well with farleft leaders. As grassroots organising at plant level was progressively abandoned, many abandoned their leadership roles to take on posts in political parties and local and regional councils. For those who remained in the trade union movement, the contradictions between its aims and achievements became a new object of contention. The union's local bargaining power progressively diminished. As neoliberal policies had an effect on industrial relations, its role was reduced to negotiating compliance with company labour adjustment plans. At the heart of the multinational, social agents have listening power under European directives, but no decision-making capacity (Kohler et al. 2006; González Begega 2011).

Ultimately, the Spanish state's continuing failure to implement a successful reindustrialisation policy (Castells 1994), and the inadequate participation of social agents in the new economy (Miranda et al 1994), have contributed to the long-term decline of industrial production in Asturias (Kohler 1996; González 2004; García Blanco 1998) ${ }^{10}$. Yet workers we interviewed expressed a conviction that, despite threats of closure, relocation and downsizing regularly used to discipline the workforce, local expertise remained central to competitive advantage, and thus continuing demand levels for high quality steel products would ensure continuing steel production in Asturias.

\section{Workers' identities, labour politics and livelihood strategies around a non- integrated steel plant}

In the small town where ACERASA is located, there is a strong identification with industrial activities even among those not directly involved in industrial work: their relatives and neighbours are likely to work in industry. The region has an international 
reputation for military ship building, and the state-owned shipyard, one of the main local employers, articulates senses of collective pride and shared representations that permeate popular and official discourses across the social spectrum. The culture of industrial work is officially acknowledged as a crucial aspect of local heritage, history and character.

ACERASA is a medium sized enterprise disconnected from the dominant industrial sector in the region. For this reason, workers' self-identification as steel makers does not transcend the boundaries of the factory or, at best, the narrow confines of their private lives. From this viewpoint, the experience of work within the plant does not directly feed the region's working-class identity, shaped by the predominance of shipbuilding industries. It is only at the level of the municipality that steel-making at ACERASA acquired some public recognition, and in the local context that public authorities and the representatives of civil society respond to the plant's activities. Conflicts between employer and workforce, or concerns about the plant's impact on the environment and on public health, sporadically attract attention across the region, but they are not regional policy or civil society concerns. Perhaps as a result of the secrecy promoted by the plant's owners, there is no clear representation of the plant and its activity in the public sphere. This may explain employees' weak identity as steel workers ${ }^{11}$. Their experience contrasts with that of workers who continued their father's tradition in the shipyards, thus fulfilling both their family's expectations and their own aspirations. Shipyard workers became increasingly identified with their work through training in the Apprentices' School -then replaced by public professional training schools- and also became entangled in the lively social networks that emerged from the shop floor, such as labour organizations, and union based associations promoting educational and cultural activities. Indeed, shipbuilding and its related activities continue to be at the centre of local identities and informs shared meanings, values and collective memories, despite the decline of the labour movement caused by restructuring processes since the $1980 \mathrm{~s}^{12}$.

The steel plant is out of step with these local representations of history. In particular, steel workers are seen -and to a great extent see themselves- as not having made a significant contribution to the political resistance that emerged from the shipyards in the 1960s, which involved wide sectors of the local working class. Throughout the 1970s, the workforce in ACERASA was not strongly organized nor connected to the 
local labour leadership on a consistent basis. As mentioned, workers at the steel plant came from a rural background, had no previous experience of industry or labour organizations, and were politically weakened by the patron-client ties that linked them to the owners' family:

"Workers in other factories did not take them into account. There wasn't a consciousness like in steelmaking in Asturias, or here in the shipyards (...). They were people who had learnt directly on the shop floor, very little trained and with no formal education [...]. It was merely a struggle for survival and for a wage at the end of each month. The situation was so distressing that they had to struggle. They knew nothing" (XCF, priest).

Only on two occasions the isolation from trade unions was partially overcome, prompted by unbearable working conditions ${ }^{13}$. But it was not until the first two decades of democratic government, when industrial restructuring dramatically affected the region and the political role of trade unions faced a serious crisis, that the representatives of ACERASA workers became involved in internal struggles. A number of improvements in working conditions, especially in relation to pay, were achieved in those years. Thereafter, labour representatives pursued their activity at grassroots level and did not covet the privileges that could have led them to an 'embourgeoisement', which their comrades in the shipbuilding sector have been accused of. It could also be the case that, given their relative isolation from union bureaucracies and the intricacy of capital-labour relations in a family-owned company where personal bonds play an important role, the plant's labour representatives would have never had actual access to such privileges. It is a widespread opinion among our participants that ACERASA's union leaders have faced the new century without losing their connection with the workers' everyday concerns ${ }^{14}$. As a non-unionised worker put it,

"I feel well represented by the workers' committee because they are workmates, and therefore they want what is best for us, just the same as me. If they were outsiders, they would not care. I could be a member of the committee, because they want for them the same as I want for me. The problem is that this company is so reluctant to negotiate... [...]. But I am sure they do all they can, if they could do more, they would do more" (R, worker). 
Still today, and despite the achievements made after much struggle, ACERASA continues to be managed in a rather authoritarian manner -a 'dictatorial' one, according to some participants- and working conditions beyond economic issues what our participants called 'social' conditions, such as the adverse environment of the plant or the organization of shift work- are unsatisfying for many. These circumstances, however, are felt to be compensated -at least partially- by the reasonable pay and the stability afforded by ACERASA jobs. As workers concede, their total wages -including productivity bonuses and other incentives- are fairly attractive within the region. After management decided not to renew temporary work contracts and to pursue production without the intervention of auxiliary companies, all workers in ACERASA are on permanent contracts. This is indeed an exceptional situation both in the wider context of the Spanish job market and in relation to a local industrial workforce that, since restructuring, tends to be hired through temporary contracts by auxiliary companies. But steelworkers stress that these 'privileges' are attained at a price. In addition to the physical risk and harshness of steel-making work, the management imposes a strict work discipline on the staff, divisions are enforced in order to prevent the development of horizontal relations between different professional groups, and few opportunities for workplace comfort or workers' selfexpression are offered. Moreover, there is little recognition of workers' needs and responsibilities outside of work, for example relating the reconciliation of production and reproduction. The latter has led to a latent conflict that places a considerable burden on domestic arrangements, an issue that is faced in particular by younger generations of workers, whose wives tend to work outside the home, and thus who do not fit the model of the breadwinner, as was the case for their older workmates (Sabaté 2017).

The combination of these circumstances has an adverse impact on the staff's experience of work and on wider social organization. As a result, while employment stability and reasonable wages continue to be perceived as an opportunity to settle down and to start a family, steelworkers feel excluded from the perceived advantages and recognition enjoyed by the small core of shipyard workers who have retained the past achievements of the regional labour movement and are seen now as an 'aristocracy of labour'. ACERASA workers only obtain their relative 'privileges' at the price of putting their health at risk, of accepting authoritarian labour relations with 
very little consideration for social needs, and of giving up opportunities for promotion or professional fulfilment.

\section{Conclusion: Global pressures, the precarisation of industrial labour, and the transformation of work cultures}

Our research in the two industrial regions accounts first of all for a quantitative transformation: the number of workers that can be identified -and who can identify themselves- as industrial labour continues to decrease ${ }^{15}$.

Yet changes in the quality of work have also deeply affected the workforce over the last thirty years, damaging their working conditions and transforming the framework where local work cultures are reproduced. We have discussed how, while SIDERSA workers mostly enjoyed privileges won by a strong union-led labour movement, ACERASA's staff faced very hard working conditions both in economic and in social terms, especially in relation to their ability -or lack thereof- to manage their time (Sabaté 2017). Even if working conditions are rapidly deteriorating for all workers across the sector, new employees experience the most precarious conditions and can only aspire at temporary employment, unlike the dwindling core of permanent workers that survived restructuring. The pressures of global markets and employers' cost saving strategies, coupled with the impact of the implementation of neoliberal reforms, have led to the emergence of a new category of 'flexible' industrial workers whose livelihoods are constantly threatened by relocation and endangered both in terms of remuneration and work-life balance.

We have described how work experiences, and the work cultures emerging from them, are different in the two locations. Both plants endured processes of organisational change, including internationalisation and the consequent threat of capital flight and disinvestment, but global changes in policy and capital flows were articulated with specific local realities, giving way to significant differences between each plant's specific labour relations, local working-class organisations, relations between factory and community, and tensions between productive and reproductive spheres. Analysing the trajectories of these companies over the past three decades, we identified three key factors that shed new light on the formation of their unique 
industrial work cultures. They were configured and constantly rearranged in relation to local, regional and global relations, generating unique entanglements of practice that shape material and symbolic aspects of work. First, we found out that the plants exhibit different distributions of privilege among the industrial labour and different actors participating in, benefiting from, or having an influence on industrial activities. Second, we analysed the changing relations around the transmission of knowledge and skills related to industrial work, and how transformations in this arena, differently paced by policy interventions in both regions, led to different perceptions of the 'quality' of work, as well as local historical constructions of steelmaking livelihoods. Finally, we explored collective constructions, transmissions and distortions of meanings and values in both local work cultures, to argue that, even though workers no longer share homogeneous working and bonding experiences in the workplace, a shared sense of the past and the future remains among them, a sense that reproduces working class identities linked to industrial activities in both the Galician and Asturian regions considered.

\section{List of Abbreviations}

ACERASA and SIDERSA are fictional names.

CCOO - Comisiones Obreras

CIG - Confederacion Sindical Galega

UGT - Unión General de Trabajadores

USO - Unión Sindical Obrera

\section{REFERENCES}

Agüera Sirgo, José Manuel. 1996. "La reconversion industrial de Asturias." In Asturias. El Declive De Una Region Industrial, edited by Hans-Detlev Köhler. Gijon: Trea. Alvarez Miranda, Alfonso, José Luis García Delgado, Luis Fernández de la Buelga, and Ignacio Herrero Garralda. 1994. Economía Y Empresa En Asturias : Homenaje A 
Ignacio Herrero Garralda, Marqués De Aledo, Biblioteca Cívitas Economía Y Empresa. Economía. Serie Especial. Madrid: Civitas.

Arrighi, Giovanni. 1985. Semiperipheral development: the politics of southern Europe in the twentieth century. Sage.

Benito del Pozo, Carmen. 1993. La Clase Obrera Asturiana Durante El Franquismo : Empleo, Condiciones De Trabajo Y Conflicto, 1940-1975. 1. ed. ed. Madrid: Siglo XXI de Espan\0303a Editores.

Benito del Pozo, Paz. 1992. El Espacio Industrial En Asturias. Barcelona: Oikos-tau. Benton, Lauren. 1990. Invisible Factories : The Informal Economy And Industrial Development In Spain. Albany: State University of New York Press.

Bogaerts, Jorge. 2000. El Mundo Social De Ensidesa : Estado Y Paternalismo Industrial (1950-1973). Avilés: Azucel.

Burawoy, Michael. 1979. Manufacturing consent : changes in the labor process under monopoly capitalism. Chicago: University of Chicago Press.

Burawoy, Michael. 1983. "Between the Labor Process and the State: The Changing Face of Factory Regimes Under Advanced Capitalism." American Sociological Review 48 (5):587-605. doi: 10.2307/2094921 .

Burawoy, Michael. 1985. The politics of production : factory regimes under capitalism and socialism. London: Verso.

Buznego, Óscar R., and Pedro de Silva. 2009. Los Inicios De La Comunidad Autónoma De Asturias : Las Elecciones Del 8 De Mayo De 1983, Días de diario (KRK). Oviedo: KRK.

Cabezas, Juan Antonio. 1975. Del Martinete Al Horno Alto : Historia De Una Siderurgia. Madrid: Gráficas Reunidas.

Carbonella, August, and Sharryn Kasmir. 2014. "Introduction: Toward a Global 
Anthropology of Labour." In Blood and Fire: Toward a Global Anthropology of Labour, edited by Sharryn Kasmir and August Carbonella. Oxford: Berghahn.

Carrier, James. 1992. "Emerging Alienation In Production: A Maussian History." Man 27:539-558.

Castells, Manuel. 1994. Reindustrialización Y Desarrollo Regional En Asturias: Problemas, Perspectivas Y Estrategias. Oviedo: Servicio de Publicaciones del Principado de Asturias.

Castells, Manuel, Juan Antonio Vázquez, and Paz Benito del Pozo. 1994a. Estrategias Para La Reindustrialización De Asturias. 1* ed ed. Madrid: Civitas.

Cerezo, J L. 2004. "El Sector De Construcción Naval En España. Situación Y Perspectivas." Economia Industrial 355 (356):185-196.

Comín, Francisco, and Pablo Martín Aceña. 1991. Historia De La Empresa Pública En España. Madrid: Espasa Calpe.

Comín, Francisco, Pablo Martín Aceña, and Fundación Empresa Pública. Programa de Historia Económica. 1996. Los Rasgos Historicos De Las Empresas En España : Un Panorama. Madrid: Programa de Historia Economica. Fundacion Empresa Publica.

Díaz-Morlán, P. and M. Á. Sáez-García (2017). "State aid for the restructuring of the Spanish steel industry from a European perspective (1975-1988)." Investigaciones de Historia Económica - Economic History Research 13(1): 38-50.

Fishman, Robert M. 1990. Working-Class Organization And The Return To Democracy In Spain. Ithaca, N.Y.: Cornell University Press.

Florido, David, Roca, Beltrán and Molina, José Luis. 2013. “Tightening the Screws: Autonomy, Collective Action, and Violence in Puerto Real During the Second Shipbuilding Restructuring”. Anthropological Quarterly, 86(3): 891-922.

Garcia Blanco, Jose Maria. 1998. "Declive Economico Y Politicas Regionales: El Caso De 
Asturias " Revista Espanola de investivaciones sociologicas 83:87-120.

González Begega, Sergio. 2011. Empresa Transnacional Y Nuevas Relaciones Laborales : La

Experiencia De Los Conités De Empresa Europeos, Investigación y Debate. Madrid: Catarata.

González Begega, Sergio, and H-D Kohler. 2010. "Transnatinal companies and the 'new' industrial relations. A vehicle to re-think the regulatory boundaries of the nation state." Revista Internacional de Organzanizaciones 4 (2010):35-52.

González, Manuel-Jesús. 2004. Hierro Y Acero Ante La Mundialización : Una Perspectiva Histórica. Sestao (Vizcaya): Aceralia, Grupo Arcelor.

Gonzalez, Manuel J. 2004. "Privatizacion E Internacionalizacion: Una Perspectiva Historica." In Hierro Y Acero Ante La Mundializacion: Una Perspectiva Historica, edited by Manuel J Gonzalez. Aviles: Aceralia, Grupo Arcelor.

Gonzalez-Polledo, E. 2015. "Politics for industrial machines: techno-political transitions in a Spanish Steel plant." In Industry and Work in Contemporary Capitalism: Global Markets, Local Lives?, edited by Victoria Goddard and Susana Narotzky. London: Routledge.

Kalb, Don and Tak, Herman. 2005. "Introduction: Critical Junctions. Recapturing Anthropology and History”. In Kalb, D and Tak, H (eds): Critical Junctions: Anthropology and History beyond the Cultural Turn. Oxford: Berghahn.

Köhler, Holm-Detlev. 1996. Asturias: El Declive De Una Region Industrial. Gijon: Trea. Kohler, H-D, V Martin Mendez, and H Van der Broek. 2006. "La Participacion De Los Trabajadores En Programas De Reduccion De Plantilla. El Caso Del Grupo Arcelor." Sociologia del trabajo 58 (2):31-61.

Köhler, Holm-Detlev, Hans Peter Van Der Doer, and Vanessa Martin Menendez. 2007. Buenas Prácticas De Vincular El Empleo Y La Productividad. El Caso Del Grupo 
Arcelor. Oviedo: Consejo Económico y Social del Principado de Asturias.

Laso, Jose Ramon. 2003. Breve Historia De La Siderurgia Integral Española, 1901-2002, .

Madrid: Fundacion Primero de Mayo.

Laso, Ramon. 2001. Trazando El Contorno De La Reestructuración A Lo Largo Del Sector Metalúrgico Europeo. Madrid: Fundación Primero de Mayo.

Leach, Belinda. 1998. "Citizenship and the Politics of Exclusion in a 'Post'-Fordist Industrial City." Critique of Anthropology 18 (2):181-204. doi: 10.1177/0308275x9801800204.

Lee, Ching Kwan. 2010. "Raw encounters: Chinese managers, African workers and the politics of casualization in Africa's Chinese enclaves." In Zambia, Mining and Neoliberalism. Boom and Bust on the Globalized Copperbelt, edited by L Fraser and M Larmer. New York: Palgrave Macmillan.

Lozano, María José and Palenzuela, Pablo. 2016. “Trabajo y culturas del trabajo en la globalidad hegemónica", Revista Andaluza de Antropología 11: 1-15.

Madrid, Juan Carlos de la. 1997. Avilés Una Historia De Mil Años. Avilés: Azucel.

Madrid, Juan Carlos de la. 2001. Paralelo 38 : Avilés Y El Siglo Xx En Cien Capítulos. $[1\{487\}$ ed. Avilés: Azuzel.

Mollona, Massimiliano. 2009. Made In Sheffield : An Ethnography Of Industrial Work And Politics. New York; Oxford: Berghahn Books.

Mollona, Massimiliano. 2009. "General Introduction." In Industrial Work And Life : An Anthropological Reader, edited by Massimiliano Mollona, Geert de Neve and Jonathan P. Parry. Oxford: Berg.

Mollona, Massimiliano, Geert de Neve, and Jonathan P. Parry. 2009. Industrial Work And Life : An Anthropological Reader. Oxford: Berg.

Montero, Alfred P. 2002. Shifting States In Global Markets : Subnational Industrial Policy In Contemporary Brazil And Spain. University Park, Pa. ; [Great Britain]: Pennsylvania 
State University Press.

Moreno, Isidoro. 1997. “Trabajo, ideologías sobre el trabajo y culturas del trabajo”. Trabajo. Revista Andaluza de Relaciones Laborales 3: 9-28.

Narotzky, Susana. 2016. "'Spain is the Problem, Europe the Solution': Economic Models, Labour Organization and the Hope for a Better Future." In World Anthropologies in Practice: Situated Perspectives, Global Knowledge, edited by John Gledhill. London: Bloomsbury.

Narotzky, Susana, and Victoria Goddard. 2015. "Industry and work in contemporary capitalism: models, markets and crisis in the global system." In Industry And Work In Contemporary Capitalism: Global Models, Local Lives?, edited by Victoria Goddard and Susana Narotzky. London: Routledge.

Narotzky, Susana, and Gavin A. Smith. 2006. Immediate Struggles : People, Power, And Place In Rural Spain. Berkeley, CA; London: University of California Press.

Navarro, Mikel. 2004. "La Larga Marcha De La Siderrgia Española Hacia La Competitividad." Economia Industrial 355-356:167-184.

Ong, Aihwa. 1987. Spirits Of Resistance And Capitalist Discipline : Factory Women In Malaysia: State University of New York Press.

Palenzuela, Pablo. 1995. "Las culturas del trabajo: Una aproximación antropológica”. Sociología del Trabajo, 24: 3-28.

Rißmann, Simone. 1996. "Ensidesa. Consorcio Siderurgico En Crisis." In Asturias: El Declive De Una Region Industrial, edited by Hans-Detlev Köhler. Gijon: Trea.

Roca, Beltrán and Florido, David. 2015. "Narrativas de la reconversión. Historias de vida, memoria social y acción colectiva en el astillero de Puerto Real". Revista de Dialectología y Tradiciones Populares, 70(1): 11-33.

Sabaté, Irene. 2017. "Getting By Beyond Work, or the Intertwining of Production and 
Reproduction Among Heavy Industry Workers and Their Families in Ferrol, Spain."

In Work and Livelihoods in Times of Crisis. History, Ethnography, Models, edited by

Victoria Goddard and Susana Narotzky. London: Routledge.

Saez Garcia, Miguel Angel, and Pablo Diaz Morlan. 2009. El Puerto Del Acero. Historia De

La Siderurgia En Sagunto. Edited by Ayuntamiento de Sagunto. Madrid: Marcial Pons.

Sierra Alvarez, José. 1990. El Obrero Soñado : Ensayo Sobre El Paternalismo Industrial (Asturias, 1860-1917), Sociología del trabajo. Madrid: Siglo XXI.

Sierra Fernandez, Maria del Pilar. 2000. "Reconversion E Internacionalizacion De La Siderurgia Integral Espanola." Economia Industrial 333 (III):101-114.

Silva, Pedro de. 1982. Asturias : Realidad Y Proyecto. Gijón: Noega.

Suaz Gonzalez, A. 2012. "La Situación De La Construcción Naval En España. Perspectivas

En Un Mercado Global." Economia Industrial 386:49-60.

Thompson, Edward Palmer. 1968 (1963). The Making Of The English Working Class.

Harmondsworth: Penguin Books.

Thompson, P. (1989). The nature of work: an introduction to debates on the labour process

(2nd ed. ed.). Basingstoke: Macmillan.

Urbano, Jose Maria. 2003. La Larga Marcha De La Siderurgia. Oviedo: UGT Asturias. Vazquez, Juan. 1994. "Asturias En El Marco De Las Regiones Atlanticas Europeas." In Economia y empresa en Asturias, edited by Jose Luis Garcia Delgado and Luis Fernandez de la Buelga. Oviedo: Civitas.

\footnotetext{
1 Despite being still today the second highest producing industrial activity in Spain (Cabezas 1975; Navarro 2004; Sierra Fernández 2000; Köhler 1996): according to data from the National Statistics Board (INE), the metal sector factored 86.604 million euros for 2007, outstripped only by the food industry.

${ }^{2}$ See Rißmann (1996), Diaz-Morlan and Saez-Garcia (2017).
} 
Preferred because of structural deficiencies as far as economic development is concerned (Benito 1992; Álvarez et al 1994), as well as imbalances across sectors of the economy.

${ }^{4} \mathrm{We}$ conducted approximately approximately 90 semi-structured interviews with workers across both sites, as well as 80 structured questionnaires with members of public organisations, training providers, and members of neighbourhood associations. We consulted the Asturian Historical Archive (www.apei.es), as well as public archives in both locations.

Local historians such as Bogaerts (2000, especially chapter 2) and De La Madrid $(1997,2001)$ address the determinant factors and social implications of the early history of the steelmaking in Avilés, with special emphasis on how the steel industry created and transformed the city.

-We visited several of these training centres during fieldwork, and interviewed training staff and centre directives. There is agreement among these personnel that the centres are undergoing changes in demand that undermine their capacity to train industrial workers.

Many of the measures through which reconversion policy was implemented were, unlike the reconversion of the mining sector, 'non-traumatic', and workers could leave with early retirement packages as younger workers entered through relay schemes.

: The Oviedo Agreements, signed in 1992, postulate that when service contracts are transferred, the winning firm must hire back all contract workers from the previous contract.

- The trade union movement suffered significantly during and after Spain's transition to democracy, as Fishman (1990), Kohler (1995) and Montero (2002) discuss with particular reference to Asturias. "Analysts of economic relations have argued that a 'culture of decline' took root in Asturias even before the rise and fall of SIDERSA. These ideas are condensed in a collectively signed manifesto (Manifiesto por Asturias, 1998), where Agüera Sirgo and other analysts outline solutions for longstanding industrial and development problems. García Blanco (1998) adds, further, that obsolescence and anachronism were culturally associated work during the process of deindustrialisation, further promoting the transition to the new light economy.

"An additional explanation for this may relate to the fact that ACERASA workers' initial training and experience was generally associated with other sectors of the economy. Especially for migrants coming from villages some distance away from the plant who were recruited when the State-owned shipyards worked at full capacity, ACERASA was an unknown employer they stumbled upon -whether through personal contact or an impersonal recruitment process.

"In this area, including a number of smaller towns situated around an estuary, the restructuring of the shipyards implemented in the 1980s and 1990s (Cerezo 2004; Suaz 2012) had a dramatic impact on the local economy, affecting not only those factories that depended directly on the shipbuilding sector, but also other activities that relied on it indirectly, for example as a result of the shipyard workers' consumption power.

" For example, in 1970-71, a long strike went almost unnoticed until a lock-out occurred and the mobilizations reached the city centre, as workers and their families held a sit-in over several nights in the cathedral of San Julián before they were evicted by the police. During the transition to democracy, a younger generation of ACERASA workers joined working-class organisations and broke the tradition of silence and lack of mobilisation.

"The only conflict in this respect occurred when most of the experienced unionists attached to the nationalist union CIG where replaced by a new, younger workers' committee that, after a short experience as a colectivo asambleario, was eventually integrated in the socialist union UGT. As both union representatives and non-unionised workers concede, the adscription to one union or the other is more a strategic matter of accessing the union's resources and facilities than a crucial ideological difference.

15 According to figures by UNESID (Union de Empresas Siderurgicas) steel sector employment peaked at 21.374 in 2008, consistently declining to 18.873 in 2016 (https://unesid.org/datos-serieshistoricas-empleo-siderurgico-en-espana.php, accessed in October 2017) 